\title{
Gender-Equality Development Strategy for Fisherwomen in Morodemak Village
}

\author{
Ani Purwanti \\ Diponegoro University, Faculty of Law, Indonesia \\ ani_purwanti81@yahoo.com
}

\begin{abstract}
Sustainable Development Goals (SDGs) are 17 goals successor strategy derived from Millennium Development Goals (MDGs) which is agreed upon United Nations state members since 2000. Gender Equality is one of its ultimate goal. As such goal is a multi-faceted issue, this paper discusses about gender equality development strategy for women who work in maritime market such as fisheries. Indonesia has a specific policy to empower fisherman which is stated in Law No. 7/2016 on Protection and Empowerment of Marine Fishers, Fish Breeders, and Salt Farmers. This policy aims to empower small-businesses in fishery markets. Although the policy is generally targeted to fishermen communities and their families, yet the policy lacks of understanding in gender equality. Fisherwomen tend to get a secondary treatment in terms of payment, roles in business and community, education and gender violence. The locus of the research is on Morodemak village. The problem in this village is the discrimination and violence targeted women in fishery community. Married women and single women are not allowed to take part in fishery business and often being neglected in their own community. Although the regional government and several NGOs have had helped these women to thrive and help their families through community business, but the patriarchy culture is still dominant which hinders their development through religious figures, village ruler, and even within the women themselves.
\end{abstract}

Keyword: Gender Equality, Development Strategy, Sustainable Development Goals

\section{INTRODUCTION}

Sustainable Development is often being associated with development in environmental issue, but this issue is not entirely true. Notwithstanding the rapid modernization in culture and economy today, sustainable development has been transformed to a global movement which becomes a guidance for development globally. In the $70^{\text {th }}$ United Nations General Assembly in September 2015 at New York, around 193 heads of state and government attended the new historical moment in which they agreed upon a new universal development plan through a document entitled "Transforming Our World: the 2030 Agenda for Sustainable Development." This document consists of seventeen goals and 169 targets which will have effects since 2016 until 2030. This document is later known as Sustainable Development Goals or SDGs.[1]

SDGs are originally a successor to Millennium Development Goals (MDGs) which were agreed by UN state parties in 2000 and ended in 2015. However, both plans have fundamental differences, either substantially or normatively. MDGs only consist of eight goals, 21 targets, and 60 indicators. Its goal is to reduce only half, or more, of any development crisis in the world.[1] MDGs gave a big responsibility to achieve, and thrive more if possible, for developing and under-developing countries without giving an equal amount of responsibilities to developed countries. Technically, MDGs also have weaknesses in its formulation and implementation. The MDGs were mandating the State Parties only through a very exclusive bureaucratic system without involving non-governmental stakeholders such as civil society organizations, academics, private businesses, nongovernmental organizations, etc.

Determined to be more effective and efficient than its progenitor, SDGs are designed to accommodate this development crisis in a more comprehensive qualitativequantitative-based plan which targeted a thorough solution upon every goal and target. SDGs are also a universal rule which mandated an equal responsibility and duty to developed countries, developing countries, and under-developing countries. SDGs bring five fundamental principles which balanced dimensions of economy, social, and environment, the principles are people, planet, prosperity, peace, and partnership. These principles are later known as 5Ps and they are indistinguishable, intertwined, and integrated between each other in order to achieve a betterment for the international community.

The heads of state and government which agreed upon SDGs have joint commitment to eradicate poverty and hunger, improve health quality, improve education, and reduce wealth inequality. This development plan also pledged a spirit of togetherness. Every human being, regardless of backgrounds, will be involved and experienced benefits from SDGs which prioritize marginalized groups, so no one will be left-behind. Indonesia itself is a diverse country, which has an enormous diversity in terms of ethnic, race, language, and belief, yet the government was committed to joining the action by implementing SDGs through Presidential Order No. 59/2017 on Sustainable Development Goals.

The spirit to actualize SDGs is, indeed, intertwined with human development as its part of the goals. In March $22^{\text {nd }}$ 2017, the United Nations Development Programme or UNDIP in Indonesian branch publicized an article entitled "Human Development Index rises but Inequality remains."[2] The article was publicized in the same day as a publication from UNDP entitled "2016 Human Development Report" in which the analysis found that the development progression has not given significant and proportional benefits for everyone, especially on minority groups such as women, minor ethnics (Chinese, Papuan, etc.), people living in remote and isolated place. Therefore, the process in achieving SDGs could be hindered if discrimination and inequality are still existing. 


\section{METHOD}

Women and children in fishery community such as Morodemak Village have not been a primary target for women empowerment campaigns and events. The proportion of work roles in workplace and business are still discriminative against women, but it is common to assign women strictly for household duties like taking care of children, producing offspring, and cooking for the family. Furthermore, the education level in Morodemak village is relatively low and has not become a priority for women and daughters to undergo higher education. The patriarchy culture is so intense which is legitimized by a rather conservative religious perspective. However, there are some NGOs who have worked with women, especially married women, in empowerment activities such as PuspitaBahari. For 12 years, the role of PuspitaBahari is very vital for empowering women and their family and tackling misogynistic culture in coastal village of Morodemak. Some of their core activities have improved the lives of the family, and particularly, the lives of the women themselves, thus PuspitaBahari got more respected in the society. Therefore, this paper will discover the gender empowerment strategy in fisherwomen community of Morodemak village and the challenges they are facing.

The kind of this research is qualitative research which analyzed through socio-legal approach. Socio-legal approach is an interdisciplinary approach which conjoins legal research and non-legal research. The former is analyzed textually and contextually in which the patriarchy logic behind the policy is considered to be very influential in the discrimination of fisherwomen.

\section{RESULT}

The marginalization of fisherwomen is a product of culture and a discriminative policy which we could identify the masculinist definition of 'fisherman' in the Law No. 7/2016 on Protection and Empowerment of Marine Fisher, Fish Breeder, and Salt Farmer. Notwithstanding the Ministerial Order of Maritime and Fisheries No. 16/2016 that becomes a legal foundation to derive regional policies in prospering fisher community, including fisherwomen such as 'fisher card'. However, the Law No.7/2016, does not give a clear definition that acknowledges the existence of fisherwomen, hence the need for recognition of fisherwomen as an equal legal subject as well as fishermen has not accommodated yet. In the Article 1(3) of the Law. 7/2016, it is defined that 'fisher' or 'fisherman' is anyone who rely on fish-catching as their livelihood. The vague definition of 'fisher' indicates the lack of acknowledgement on women's role and involvement in the phases of pre-production, production, and postproduction of fishery industry. The word 'woman' is only mentioned once in Article 43 which concerns on women's role in the 'household' of fishers, fish breeders, and salt farmers. This article also indicates that the role of women in fishery is acknowledged in domestic level only. The lack of further definition on women's role closes to the interpretation on the possibility of women efforts in prospering their family, at least in economic level.
The past research from KIARA (People's Coalition for Fishery Justice) discovered that 48 percent of revenue from fisheries in fisher family is earned by fisherwomen [3]. According to Adhuri and Gina [4], fishery activity is not understood merely as fish-catching which is culturally done by men, but also involved women in some processes like preparation, preservation, and packaging process. Therefore, the existing definition on 'fisher' and 'fishery' must be changed, modified, and adapted with the reality in coastal villages like Morodemak so that the legislation could accommodate the multi-faceted issue with holistic and integral understanding.

Furthermore, the definition of 'fisher' must be inclusive in which it encompasses the doing of anyone who involved in fisheries or livelihood that based on maritime resources, including women. An inclusive definition could impact the lives of fisherwomen to the betterment in which the implemented activities from the Law No. 16/2016 such as government-funded workshops, training, and business loans could be applied to them.

Gender equality is a condition where women and men are treated equally either on legally acknowledged rights and the opportunity to pursue the betterment of livelihood. Gender equality is a critical issue nowadays because of the rising awareness on women discrimination which is constructed by patriarchy culture and system [5]. The government must respect, fulfill, and protect human rights, including women rights, through legislations and its following implementations. Understanding gender equality basically represents human rights as a whole because humans are born with equal dignity. Hence, through gender equality framework, the state must guarantee the fulfillment of equal treatment between women rights and men rights in politics, economy, social, and culture. There are 3 principles in gender equality which are 1) substantive equality, 2) non-discrimination, and 3) state duty to respect, fulfill, and protect.

The portrayal of Morodemak's fisherwomen represents the challenges what fisherwomen across in Indonesia are facing now. The challenges are the low rate of education, lack of access, control, and participation on activities and facilities that could be used for theirs and their family's livelihood. Many villagers of Morodemak have not known or acknowledged about the existence of fisherwomen as an economic agent for coastal society. Prejudices still exist are; 1) that there is no fisherwoman, there is only fisherman's wife; 2) that women who process and sell the catches are not a fisher; 3) no woman can go seaward.

Masnuah, a fisherwoman activist in Morodemak village stated that fisherwoman is a woman who is involved in any fishery activities either in fishing, processing, packaging, and selling process. Furthermore, the categories of fisherwomen are actually very broad. There are women who work as a literal fisher, a fish breeder, a salt farmer, a raw processor, and a fish seller. Masnuah also argued that the definition of fisherwomen must be represented and widen contextually. This is because the existing prejudice about 'fisherman's wife' is discriminative and derogatory. The impacts of which are 
denigrating, the appreciation (e.g. salary) for women's credits on fisheries could be taken away with impunity yet women still experienced violence and denigration of dignity whenever there is a flaw in their works.

PuspitaBahari is a non-governmental organization founded by Masnuah. Its objective is to elevate the livelihood of fisherwomen, particularly in Morodemak and neighbor coastal villages. They have several empowerment strategies for fisherwomen in Morodemak village, such as:

a) empowering economic for fisherwomen, matriarchs, and women victim of violence. Economic activities are chosen to pursue a substantial economic independency so that these women would not be trapped in a circle of violence and discrimination. Furthermore, the primary activity of this strategy is women entrepreneurship through collective homemade businesses such as fish crackers, terasi (fermented shrimp paste), salted fishes, smoked fishes, and other fish products. The activity also encourages married women to process some of their husbands' catches.

b) offering 'grocery saving' which is a form of collective self-banking. The procedure is every member, divided in small groups, must input some money into a saving lot by which the lot later will be given for members who in need by portions through lottery.

c) facilitating economically under-developed women in some government aid programs such as healthcare, cash aid, or social security.

d) raising funds for women victim of violence for their initial capital of livelihood.

e) facilitating advocacy and rehabilitation for women victim of violence

f) facilitating medical tools for disabled women such as wheelchair and hearing aid.

g) Facilitating social aids for elderly women.

\section{CONCLUSION}

The government should pay special attention to the fisherwomen and change the definition of fishermen that exist in Law No. 7/2016 on Protection and Empowerment of Marine Fisher, Fish Breeder and Salt Farmer are still discriminative against women, otherwise it will impact on the achievement of Sustainable Development Goals, especially related to equality gender is especially important factor that is eradication of poverty, food security and development sustainability.
The economic progress of the fishery sector is not just about the contribution of men but also fisherwomen in terms of gaining recognition, identity, and access of facilities.

Development of Gender Equality in Morodemak Village is conducted with economic empowerment agenda especially for matriarchs, fishers' wife, and woman as a victim of violence. Economic activity is chosen because after being economically empowered, fisherwomen can be independent and not trapped in violence circle, the priority of activities that are done and developed are post-production activities such as; making fish crackers, shrimp paste, salted fish, smoked fish, and other fish products. Economic empowerment is also done by inviting the fishermen's wife to cultivate the catch of husband. Other programs are utilizing "grocery saving" during the scarce season, facilitating access to public services such as healthcare, social security, and medical tools for disabled women.

\section{REFERENCES}

[1] S.; Panuluh and M. R. Fitri, "Perkembangan Pelaksanaan Sustainable Development Goals (SDGs) di Indonesia 2015-2016," 2, 2015.

[2] "No Title." [Online]. Available: http://www.id.undp.org/content/indonesia/id/home/press center/pressreleases/2017/03/22/indonesia-s-humandevelopment-index-rises-but-inequality-remains-.html,

[3] Andi Misbahul Pratiwi, Masnuah, Pejuang Hak-Hak Perempuan Nelayan, Jurnal Perempuan Volume 22 No 4 November 2017.

[4] Naufaludin Ismail, Perjuangan Rekognisi Identitas Hukum Perempuan Nelayan Ujung Pangkah Gresik, Analisis Femisis Terhadap Kebijakan Kartudan Asuransi Nelayan, Jurnal Perempuan Volume 22 No 4 November 2017.

[5] Dedi Adhuri dan Abby Gina, Marginalisasi Perempuan Nelayan adalah produk Kultur dan Kebijakan yang Diskrimatif, Jurnal Perempuan Volume 22 No 4 November 2017.

[6] Kementerian Pemberdayaan Perempuan dan Perlindungan Anak, Parameter Kesetaraan Gender Dalam Pembentukan Peraturan Perundang-Undangan, 2016 